\title{
A 20-Year-Old Study* The Fethullah Gulen Group: Where Does It Stand in Relation to the Nurju Movement?
}

\author{
20 Yıllık Bir Araştırma: Nurculuk Hareketiyle İlişkisi İçinde \\ Fethullah Gülen Grubu Nerede Durmaktadır?
}

\section{Fahri Çakı}

\section{$\ddot{O} z$}

İşadamı nurcular ve entelektüel/kadro nurculardan oluşan iki grup nurcu katılımcılarla yapılan 20 derinlemesine mülakat verilerine dayanarak bu maka-

\footnotetext{
*I conducted an ethnographic research, for my doctoral dissertation, 20 years ago. It focused on new social classes and the nurju movement in Turkey. While writing it, I noticed a call for papers. Because it was about the Gulen group, a theme partly related to my dissertation, I applied and got a chance to make an oral presentation on the topic of this paper. I realized, when arrived there, that the symposium was organized by the group itself. Among the participants there were many academicians some of whom are in quite important political positions today. All papers delivered in the symposium were gathered together and published by Hakan Yavuz, the editor. There was only one exception: this paper of mine. I understood that my paper was not wanted to be published mainly because it touched someone on his sore spot. While all other papers praised the Gulen group, my paper revealed many critical points. After return back to my country, I had to face some other problems due to the topic and content of my dissertation. So I never published anything on the same theme. But today the topic is the hottest one in Turkey. And I realize how important my study was. This paper was written in 2000. Thus it reflects the issues and topics of that time. However, they are still relevant, in many ways, to the discussions of today. Therefore, I decided to submit the paper ones again to any journal willing to publish it. Being written by an inexperienced young $\mathrm{PhD}$ student at the time, it may have some shortcomings, especially in terms of theoretical framework. It was an option for me to strengthen it from this aspect but it was already too long. So, I decided not to do so and I kept the paper in its original text without making any correction or adding anything new, except the phrase of "A 20-Year-Old Study" on the title. I think the paper as it is would still help the reader to see how the issue was perceived 20 years ago and compare it with the present time. And this is the main motivation behind publishing it today.
}

Fahri Caki is [was] a doctorate candidate in the Department of Sociology at Temple University, Philadelphia, PA. The author wishes to thank Kyriakos Kontopoulos and Mary Stricker for their comments and to everybody else who helped him to realize the research.

[The author now teaches at the Department of Sociology, Balikesir University, cakifahri@yahoo.com ].

Bu makale iThenticate sistemi tarafından taranmıştır.

Makale gönderim tarihi: 18.08.2017

DOİ: 10.17550/Akademikincelemeler.335295 
le, nurcuların Nur hareketiyle ilişkileri bağlamında Fethullah Gülen grubunu nasıl algıladıklarını incelemektedir. Araştırma bulguları, Fethullah Gülen grubunun siyasal ve ideolojik pozisyonlarını değerlendirirken nurcu olmayanlar gibi bizzat nurcuların da kendi aralarında farklılaştıklarını göstermektedir. Geniş kapsamlı genellemeler yapmaktan dikkatle kaçınarak makale, bu farklılaşan görüşlere sınıf-temelli bir analiz sunmaktadır.

Anahtar Kelimeler: Nurcu Hareket, Fethullah Gülen Grubu, İslam, Türkiye

\begin{abstract}
Based on twenty in-depth interviews with two types of nurju participants, businessmen nurjus and intellectual/cadre nurjus, I inquire how nurjus perceive the Fethullah Gulen group in relation to the Nurju movement. The research findings show that the nurjus too differ among themselves -as nonnurjus do- in evaluating the political and ideological position of the Fethullah Gulen group. With a careful avoidance from broad generalizations, I offer a class-based analysis for the interpretation of the differing views.
\end{abstract}

Keywords: Nurju Movement, Fethullah Gülen Group, İslam, Turkey 


\section{Introduction}

The Nurju movement ${ }^{1}$, being the oldest moderate Islamist movement which is probably peculiar to Modern Turkey, was broken into several groups since Said Nursi, the founder of the movement, passed away in 1960. At the present time, there are more than ten nurcu groups with different agendas and strategies. Despite all their differences, today the Nurju groups seem to acknowledge each other's identity and try to keep a certain level of solidarity. The place of the Fethullah Gulen group within the Nurju movement, however, seems to be a bit shaky.

Fethullah Gulen (b.1938) split himself, at least in appearance, from the overall Nurju movement in 1972 and succeeded in establishing his own group with a strong organizational structure in the 1980's and the 90's. Due to the development of its broad school network both in Turkey and abroad ${ }^{2}$, his group attracted attention. Those schools fascinated not only Islamist businessmen and middle classes but also a large number of secularist intellectuals and politicians. Although it originally emerged out of the overall Nurju movement, some believe that the number of the followers of the Fethullah Gulen group is much larger than that of the total of the rest of the nurju groups. Yet, there seems to be enough reason to think that there was a price to pay for this success: alienation from other Islamist groups as well as from the overall Nurju movement of which the Fethullah Gulen group ${ }^{3}$ itself is supposed to be a part.

An examination of Turkish newspapers and journals would easily reflect what non-nurjus think of Fethullah Gulen and his group. Approaches to the Fethullah Gulen group can be classified in two broad groups: 1) those who approach the group as a segment of the civil society trying to harmonize tradition with modernity, something that the Kemalist modernization project failed to achieve, and 2) those who

1 For scholarly studies of the Nurju movement, see Mardin (1989), Nereid (1997), Yavuz (1998).

2 Ozdalga (1999) presents a nice study of those schools.

3 For a discussion of the Fethullah Gulen group in relation to the Nurju movement, see Yavuz (1999) and Komecoglu (2000). 
approach the group as a new version of fundamentalist movements manipulated and used by "backward interior enemies" as well as by "imperialist foreign forces"4.

However, what nurjus themselves think on this matter is as important as what non-nurjus think and, to my knowledge, there is not much work on this.

In this paper, which is a part of a still-ongoing study, I inquire how members of the overall Nurju movement perceive the Fethullah Gulen group. Do they still perceive this group as a part of the Nurju movement or as a separate entity? What are the major points of disagreement, if any, between the Nurju movement and the Fethullah Gulen group? Within the Nurju movement, who, if any, are most likely to see the Fethullah Gulen group as separate from the Nurju movement? In other words, does the perception of the Fethullah Gulen group significantly differ, if it does at all, among Nurju members according to their class position? By discussing these questions, I aim to contribute to the sociological understanding of the Nurju movement in Turkey.

Why does the perception of the nurjus upon the Fethullah Gulen group matter? It matters because the nurjus have closer relations with the Fethullah Gulen group than anybody else does. Any information stemming from these relations may shed light on some aspects of the Fethullah Gulen group as well as on that of the Nurju movement itself. Furthermore, it matters because it may help us to understand to what extent the Fethullah Gulen group may have the support of the Nurju movement.

The research focused upon the perceptions of two types of nurju participants: 1) businessmen supporting the movement, and 2) intellectuals and cadres of the movement. Before proceeding further, a few points need to be made regarding some characteristics of those two types of participants.

As I argue in detail in my still-ongoing work, businessmen supporting the Nurju movement are neither members of big bourgeoisie

4 See, for instance, a collection of papers in Kaynak Yayinlari (1999). 
operating under the triple alliance type of economic activities nor that of traditional petty bourgeoisie struggling to survive. Instead, they represent a new indigenous industrial class who are "making it" but who also want to expand their existing power especially in relation to the triple alliance ${ }^{5}$ dominating the Turkish economy for the last several decades.

Intellectuals and cadres of the Nurju movement, on the other hand, can be seen as segments of middle classes struggling to survive under harsh economic conditions. Although they hold higher educational degrees and skills, they are frustrated with the limited opportunities the politico-economic system generates for them. They work in Nurju organizations for a living. Thus, Nurju organizations hold a central position for them.

Because of their differing class positions in society, businessmen nurjus and intellectuals/cadres of the movement are likely to look at certain things differently. Based on this logic, I hypothesize that the perception of the Fethullah Gulen group by nurju members does differ primarily by the extent of relationships and similarity (or closeness) of interests with the Fethullah Gulen group rather than by group affiliation. In other words, I am expecting to find both sympathetic and critical views on the Fethullah Gulen group depending on how deep one's individual and/or class interests are with this group.

\section{Methodology}

This particular research is part of a larger ethnographic study trying to locate the Nurju movement within the developmental context of modern day Turkey. The primary source of data for that original study was based on observations on Nurju organizations and on 52 in-depth interviews carried out in Istanbul, Adapazari, and Ankara mostly in the summer of 1999.

5 I borrow this concept from Evans (1979) who means, by this concept, an alliance between multinational corporations, the local bourgeoisie, and the state. Such alliance emerges during the stage of dependent development, which benefits all partners of this alliance. 
The advantages and disadvantages of ethnographic studies are well discussed in the literature ${ }^{6}$. In addition to its well-known advantages, I have chosen this methodology for a practical reason: this research aims to reflect the views of two types of nurjus: Businessmen nurjus and intellectuals/cadres of the Nurju movement whom I see as the key figures in the process of forming the nurju discourse. Since businessmen nurjus are usually not involved in writing in any place, in-depth interviews is the best way of obtaining information about their views. Intellectuals/cadres of the movement do write but they oftentimes understandably hesitate to comment publicly on this particular subject because this may offend the targeted people with whom they may need to work in the future. In-depth interviews best serve for the purpose of this particular research too.

The whole fieldwork including the interviews took seven months. All the interviews were audio taped. The longevity of the interviews ranged from one hour to four hours. All the interviews were made in Turkish. Upon completion, I transcribed and coded them for the process of analysis. I did most of the transcriptions by myself, which gave me the opportunity to become familiar with my data, to discover frequently used terms by members, and to notice some patterns, similarities and connections in the responses of the respondents.

How did I establish my population and how did I draw my sample from this population? In other words, whom did I include in and whom did I exclude from the study? It should be noted here that nurjus do not like terms like Nurju, Nurjuluk, or Nurju movement. Instead, they prefer terms such as Risale-I Nur talebesi ${ }^{7}$, and Risale-I Nur Hizmeti ${ }^{8}$. As a common characteristic, there is no official record of membership in the Nurju movement ${ }^{9}$ as is the case in many other

6 See, for instance, Shaffir and Stebbins (1991).

7 The Risale-I Nur is the collection of Said Nursi's writings; it can be translated to English as the Epistles of Light. Risale-I Nur talebesi means the student of the Risale-I Nur. 8 The term Risale-I Nur Hizmeti refers to any service trying to spread and realize the discourse of Said Nursi.

9 Estimates regarding the number of nurju followers range from 1 million (Nereid, 1997; 106) to 6 million (Yavuz 1999;590). 
Islamist movements. So, my criterion for interviewing nurjus was basically the self-claim of the respondents. Anybody claiming to be a nurju should be seen as a nurju in my view. At the beginning of each interview, I asked my respondent if he claimed himself to be a nurju according to his own judgment. In a few cases, the respondent evaluated the Nurju movement as a significant form of the overall Islamist movement but did not necessarily identify himself particularly with this movement. I did not consider such persons as a nurju and, therefore, excluded them from the study. Other than this, I took the self-judgment of the respondents as the primary basis of my approach to membership.

In terms of what makes someone to consider himself as a nurju, I came to think that one identifies himself with the Nurju movement if he a) regularly experiences the activity of reading the Risale-i Nur, at least for a while, in various Nurju meetings as well as on his own, b) believes (or chooses to believe) in the superiority of the Nurju movement over others in terms of both theoretical basis and strategic practices and c) participates in the nurju activities in his own ways.

I excluded nurju women from the study for one theoretical and one practical reason: Theoretically, I am not interested in exploring gender issues in the movement although this might be a fruitful subject for another study. Also, due to the Islamic regulations on gender relations, it would be practically difficult for me as a man to be in contact with nurju women.

Likewise, I excluded members of marginal nurju groups holding a Kurdish agenda for two reasons. First, theoretically it is the perceptions of mainstream nurjus that I want to examine. Second, in order to include this type of nurjus in my research, it would have been necessary for me to go to the Eastern and Southeastern Anatolia, which was both dangerous and beyond my available financial resources. Therefore, although I am aware of possible regional variations in the movement, I did not design the research in a way that could cover regional differences. This could be seen as one of the weaknesses of this research.

In short, all my respondents are male members of mainstream Nurju groups, who identify themselves, without any hesitation, with 
the Nurju movement. For the purpose of the present paper, I excluded nurjus who identified themselves specifically with the Fethullah Gulen group. The rationale for this exclusion was of course my assumption that I would not find any significant critical view among them toward the Fethullah Gulen group. More importantly, I excluded them because I want to know how much support they have from outside of their own circles, in this case, from members of other Nurju groups.

All those members who were included for this research are "sustaining participants" of the movement because they have been participating in the movement for at least five years and are still actively involved in the movement.

Finally, I would like to touch on the generalizability of the conclusions stemming from the research. To me, this is the weakest point of my research for at least two reasons in addition to the above issues: First, the number of the respondents is not large enough to reach generalizable conclusions on the movement under study. Indeed, the analysis in the present paper is based on only twenty interviews (eight businessmen and twelve intellectual and cadre nurjus). Second, the study excludes some segments of the movement -that may indicate gender variations, regional variations and group variations-- that may display quite different characteristics than the picture I have drawn in this research. Therefore, my conclusions on the movement have to be seen as "partial truths" in terms of both its technical content and my active involvement in collecting and interpreting the data. As such, my purpose in this research is not reaching at generalizable truths but getting and reflecting the insider's view on the subject matter of the research.

\section{Research Findings}

The research findings seem to support the hypothesis outlined above; that is, the findings show that there are indeed differing perceptions within the Nurju movement regarding the Fethullah Gulen group. While some nurjus tend to have an overall sympathetic view of the Fethullah Gulen group and locate it within the Nurju movement, others adopt a more critical view and locate it in the margins or outside of the Nurju movement. Furthermore, the findings show that there is a correlation between class position of the respondents and their perception of the 
Fethullah Gulen group. Considering the limited space allowed for this paper, I will restrict my discussion to six issues to illustrate the differing perceptions of the Fethullah Gulen group by the participants of the Nurju movement.

\subsection{The Location of the Fethullah Gulen Group: In or Out?}

As mentioned earlier, the Nurju movement is fragmented into more than ten groups. The first fragmentation took place in the 60's soon after Said Nursi passed away, then, others followed in the 70's and especially in the 80 's. What motivations lie behind those fragmentations? The information gathered from the interviews shows that businessmen nurjus do not take fragmentation as a shortcoming or weakness; rather, they see nurju groups as specialized organs of the same body. In other words, all groups within the Nurju movement are appreciated in terms of a sort of division of labor. The following quotation exemplifies the typical explanation presented by businessmen nurjus:

Everybody is created with different talents and tendencies; therefore, everybody tries to serve the Risale-I Nur in accordance with his talents; fragmentation is an inevitable outcome of those different talents and tendencies. Some are more talented in intellectual and political issues; therefore they try to serve along with those talents. Some are more talented in organizing people and producing concrete works, therefore, they use these talents to contribute to the education of our people. I do not see any problem here $(B \# 42 ; 5)^{10}$.

The Fethullah Gulen group is seen, therefore, as just another organ of the same movement. Some businessmen nurjus look at the spirit of the Risale-I Nur's philosophy in determining the Fethullah Gulen group's location in relation to the Nurju movement. Respondent \#51, for example, sees the Fethullah Gulen group as perfectly matching this spirit.

10 In order to keep the confidentiality of the interviews, I used numbers instead of real names to refer to respondents. I also used letters such as "B" (businessman), "I" (intellectual), and " $\mathrm{C}$ " (cadre) to indicate what category the respondents belonged to. The final number in parentheses at the end of each quotation refers to the page number of the transcribed forms of the interviews. 
Hocaefendi $i^{11}$ and his group reveal the best effort and model for the Risale-I Nur's principles in education. The main philosophy of the Risale-I Nur is to create a society dominated by highly educated, enlightened people who can question and reason their own time in the lines of past-present-future relations (mazi-hal-istikbal). This is not a negative attitude of questioning but a positive one. As our prophet once said, we are the warriors of love; we do not have time and energy for hostility (Biz muhabbet fedaileriyiz, husumete asla vaktimiz yoktur). Hocaefendi and his group are trying to realize exactly this philosophy. In doing so, they show no sign of worldly interests, be it personal or group $(B \# 51 ; 6)$.

Other businessmen nurjus, like respondent \#49, look at the Fethullah Gulen group in terms of the benefits they generate for the country. Mostly those benefits are highlighted around the group's schooling activities abroad. Respondent \#49 points out another aspect of those benefits, that is, creating a positive image of Turkish people and culture.

Fethullah Gulen group's activities abroad are very useful and important for our country. Turkey is not known in the outside world. There are lots of misunderstandings and prejudices about Turkey. Unfortunately, the state fails to clear up those misconceptions about us. Fethullah Gulen's group sets good examples of real Turkish people abroad. Through them the outside world develops a more positive view of Turkey and the Turkish people (B\#49;10).

Although businessmen nurjus do not seem to have a notion of fragmentation within the Nurju movement coming out of personal/ class interests, respondent \#40's following statement highlights a possibility of fragmentation within the Fethullah Gulen group, a fragmentation that would be created and encouraged by European countries. They would want to do such a thing, according to him, because

11 This is how Fethullah Gulen is addressed in Turkey. 
schooling efforts of Gulen's group are likely to generate a native elite group in those countries; after graduation, the students of those schools will hold important positions in their countries and develop good relations with Turkey. This, in turn, will contribute to the growth of Turkey's strength. Since Europe is able to foresee this danger and since she does not want to see a strong Turkey, European countries would like to split the Gulen movement to prevent this outcome $(B \# 40 ; 6)$.

Furthermore, businessmen nurjus are also aware of the possibility that outsiders could perceive Fethullah Gulen and his group as if they were not part of the nurju movement. However, this is a misjudgment, they think, stemming from looking at the appearance rather than the essence of the group. Due to his conscious public appearance, Fethullah Gulen himself as the leader of the group plays an important role in the emergence of this misjudgment. Respondent \#40, for example, points out this as follows:

To me, Fethullah Gulen is not out of the nurju movement but he wants to present himself and his group as if they were not nurjus. This is a requirement of the types of services that he and his group are desirous for $(B \# 40 ; 7)$.

The information presented above shows that businessmen nurjus have an overall positive view of the Fethullah Gulen group and situate it solidly within the nurju movement. However, this does not mean that they have no criticism at all. Respondent \#50's following statement shows that they do have some concerns about the role of the Risale-I Nur for this group:

In the Fethullah Gulen Group, Bediuzzaman and the Risale-I Nur appear to have a secondary position whereas Fethullah Gulen and his audiotaped cassettes hold a primary position. This is probably not something Fethullah Gulen himself desired but that is how it looks like. If believers make some minor mistakes, Bediuzzaman says, they receive compassionate slaps from Allah. The recent troubles Fethullah Gulen is facing might be this kind of compassionate slaps (B\#50;39). 
As I will show below, businessmen nurjus do not approve of all of Fethullah Gulen's positions. However, criticisms are generally seen as "minor mistakes" as in respondent \#50's words. Furthermore, the phrase "compassionate slaps" implies that businessmen nurjus still consider the Fethullah Gulen group within the movement. Those slaps are "compassionate" because they serve the Risale-I Nur, therefore, to Allah's path.

Although some of the intellectuals/cadres take a similar position with businessmen nurjus, most of intellectuals/cadres of the Nurju movement seem to draw a significantly different picture regarding the Fethullah Gulen group. For them, the attitudes of the Fethullah Gulen group are not "minor mistakes" at all. They reflect fundamental differences, they assert, between the Fethullah Gulen group and the Nurju movement. Respondent \#23 highlights two major differences: the role of leadership and the goal of state control:

We split from Hocaefendi in 1972. He has ideas peculiar to himself. He thinks we are passive and slow; he wants to be active and quick. Since then, he never said he was a nurju. He would not say that today either. Both he himself and his followers benefit from the Risale-I Nur but they do not have the perspective of a nurju. In his group, there is a charismatic leader, Fethullah Gulen, whereas, in the nurju movement, there is no such personality. Instead of a charismatic leader, we put greater emphasis on the spiritual leadership of the Risale-I Nur (sahs-i manevi). In other words, in his group, Fethullah Gulen is the center; his word is the last word. The perception of the Risale-I Nur is based on his own interpretations. He aims to get state control through encouraging his followers to occupy state offices. In Turkey, all Islamist groups -except the Nurjus- have this same goal $($ I\#23;5).

The quotation above shows that secularists accusing the Fethullah Gulen group as trying to get state control are not alone; some nurjus too have the same impression about the group. Of course, Fethullah Gulen always rejects this kind of accusations. However, intellectuals/ 
cadres of the Nurju movement do not find those rejections persuasive enough. Respondent \#19, for instance, thinks that Fethullah Gulen and his group are unrealistic and full of anxieties:

He [Fethullah Gulen] is full of anxieties in recent years. He often receives news of military coups from some unknown sources. When he receives such news, he immediately takes a defensive position. He makes some speeches and tries to prove how his group is far away from politics. In doing so, he assumes that state rulers would not want to harm him and his group's activities. But this is unrealistic; he and his group are used by some people. (I\#19; 13).

According to respondent \#24, what distinguishes the Fethullah Gulen group from the Nurju movement is primarily the understanding and practice of the service (Hizmet). He describes the differences as follows:

They [the Fethullah Gulen group] want to read the Risale-I Nur but they want to determine the content and form of the service by themselves, they are not satisfied with the content and form determined by Said Nursi. Therefore, in a sense, they see themselves above Said Nursi. They read the Risale-I Nur but they are not nurjus in the sense of the Risale-I Nur's understanding of services and goals. (I\#24;6).

Respondent \# 20 thinks that the followers of Fethullah Gulen suppose that his ideas are original but in reality most of his ideas come from the Risale-I Nur. They are not aware of this, he thinks, because they do not read the Risale-I Nur enough. Furthermore, the social basis of his followers is the Nurju movement, he adds. For these reasons, they should not be seen outside of the Nurju movement. However, Fethullah Gulen also has some ideas that contradict with the Risale-I Nur; therefore, "one foot of the Fethullah Gulen group is inside the Nurju movement while the other foot is outside of it."

Intellectuals/cadres of the Nurju movement also distinguish the Fethullah Gulen group from the Nurju movement in terms of political 
actions concerning Islamist groups in the country. Respondent \#24 says:

Our movement opposes every action against Islam. For example, we oppose the state policies against the banning of Qur'an Courses, against that of Imam-Hatip schools, against the headscarf, etc. But the Fethullah Gulen group does not show the same attitude on these issues (I\#24;7).

These interviews suggest that businessmen nurjus see no problem in locating the Fethullah Gulen group within the Nurju movement whereas intellectuals/cadres of the Nurju movement express strong reservations on the suitability of this approach. The views of the nurjus upon the following issues further illustrate the rationale for why they locate the Fethullah Gulen group the way they do.

\subsection{The Schools of the Fethullah Gulen Group}

Almost all of the businessmen nurjus prefer the Fethullah Gulen group's schools for their school-aged children, which, according to the statement of respondent $\# 42$, cost about $\$ 3000-3500$ yearly per student. A few reasons are given for why businessmen nurjus have their children study in those schools. The most common reason is to provide a better education for children. The following quotation well illustrates this:

-- Why did you prefer such a school for the education of your daughter?

-- Because I want my kid to have a good education. This preference is not based on our desire to give her a religious education. We ourselves do that at home (B\#44;p.3).

In addition to the reason of good education, respondent $\# 41$ mentions another one:

-- Are your children studying in Fethullah Gulen group's schools?

-- Yes but that is not so important for me. What is important is first that my kids get an education in accordance with our own values, and secondly that they get a real quality education (B\#41;p.2). 
The following quotation from respondent \#40 illustrates the point that the nurju business elite needs a certain type of school for their children. Those schools do not necessarily have to be owned and run by nurjus but they have to provide an elite education with an emphasis on religious/ethical values.

The most important thing is the quality of education in these schools. In public schools, there are 60-70 students in a single class. It is impossible for those students to get a good education. Furthermore, my children's school Ihlas College-contributes to the spiritual development of my children as well.

-- That school is not one of the nurju schools if I am not mistaken?

-- It is not that important. What is important is that my children get a quality education over there and they stay away from harmful habits (B\#40;p7).

Finally, another reason concerns adolescent daughters. Respondent \#42, for example, explains the reason why he preferred the Fethullah Gulen group's schools for his daughters in terms of "religious requirements on the headscarf." Because it is impossible to observe the headscarf requirement in public schools, he says, he chose one of those schools for his daughters six years ago. However, he also adds that the headscarf is not the only criteria:

I would still prefer those schools if I had more schoolaged daughters in spite of the fact that it is no longer possible to observe the headscarf requirement even in those schools. This is so because the headscarf is not the only important thing about those schools. They are still able to raise our children in accordance with our ethical and religious values (B\#42;4).

Intellectual nurjus seem to show two positions in this regard. One group of intellectuals (respondents $\# 14, \# 15, \# 18, \# 21$ ), who are wealthier than the others, does prefer private schools run by the Fethullah Gulen group for their children, as is the dominant case for bu- 
sinessmen nurjus. The reasons for why they prefer this type of schools are almost the same with the ones expressed earlier by businessmen nurjus. The other group of intellectuals (respondents \#16, \#19, \#20 and \#23), however, seems to be critical of those schools for several reasons.

First, as respondent \#16 expresses it, those schools are hard to afford for middle class families.

The second point of criticism is the characteristic aspects of education in those schools. In this regard, respondent \#19 asserts that what is important in those schools is the success of the school, not that of individual students. "They aim to realize success in mass education. This way they get credit for themselves. They choose only potentially successful students. The success of those students becomes the success of those schools," he says. According to him,

those schools even impose the choices of their senior students about their fields of study and colleges so that those students would not fail in the nationwide college entrance exams. If the students fail, it influences the reputation of the school. In other words, the students'own choices have no chance. Another thing is that they force students to study at an extreme extent. Students are like racing horses in those schools. Eventually, there is a success but for what cost? Those schools fail in making a real contribution to the development of students' personality (I\#19;p.4).

Students in those schools, respondent \#20 thinks, live in a "cocoon $^{12}$." What he means by this is that they live in a homogeneous environment occupied by children coming from more or less the same social-familial background and that they grow up without knowing about the real life outside of this environment. "I prefer my children studying in ordinary public schools rather than living in a 'cocoon," he says.

A third point -the sharpest one- respondent \#20 makes regarding those schools is that those schools are not "private" at all. He thinks

12 The respondent used the term "fanus" for which I used the term "cocoon" to give the closest meaning. 
that there is neither a "civil society" nor a "private educational system" in Turkey; rather, there is a "strong state" dominating all aspects of life including those schools. He presents the following explanation to demonstrate his point:

As we all witnessed during the February 28th process, particularly the schools of the Fethullah Gulen group acted as if they were more Kemalist than Kemalists themselves. When the state authorities made their first statements against the headscarf, the administrators of those schools showed no sign of resistance. Quite to the contrary, they forced their female students to take off their headscarves at school before they [the administrators] were officially asked to do so (I\#20;p.12).

\subsection{The Headscarf Controversy}

In the 1998-99 academic year, the National Board of Higher Education, YOK, issued a ban against the practice of wearing the headscarf in universities. The justification for this ban was presented on the argument that the headscarf has become "an ideological symbol" of fundamentalist movements attempting to attain power ${ }^{13}$. The reaction of students wearing the headscarf toward this ban was a number of demonstrations and protests. However, those demonstrations and protests could not change the YOK's decision. As a result of the strict practice of this ban, an estimated 37,000 students wearing the headscarf were deprived of their right to a college education ${ }^{14}$.

While those student demonstrations were taking place, Fethullah Gulen made a public statement arguing that the headscarf is not a matter of faith but a cultural practice ${ }^{15}$. Furthermore, rumors started circulating that the Fethullah Gulen group encouraged its female followers to abandon their headscarves to be able to attend their schools. Because the headscarf issue and Fethullah Gulen's statement

13 For an example of attempts to justify this ban, see Turkish Daily News, article on Turkish National Security Council Meeting, March 28, 1999.

14 Ali Bulac's article in Daily Zaman, October 14, 2000.

15 For this statement, see Yeni Yuzyil, 16 September 1998. 
about it became a big deal among Islamist groups including the Nurju movement, I wanted to find out how the nurjus feel and think about it. Oftentimes, they themselves brought this issue into the middle of conversation before I asked about it.

Only one of the businessmen nurjus -a young businessman who had a wife studying in a college- expressed a strong tone of criticism regarding Fethullah Gulen's attitude toward the headscarf problem. As the following quotation from him illustrates, he blames Fethullah Gulen for breaking the solidarity among Muslims toward forcing the state to solve this problem:

The headscarf is farzi-ayn for women, it is not farzi-kifaye $^{16}$. Abandonment of the headscarf causes serious psychological problems for women with headscarves. Therefore, I do not approve of Fethullah Gulen's statement about abandoning it. This statement caused a serious division among Muslims. The followers of Fethullah Gulen abandoned the headscarf while another large group of Muslim women tried to resist the state's force on this matter. As a result, state officials got more convinced that the headscarf is indeed a political symbol, not a religious requirement. This is of course wrong and Fethullah Gulen is responsible for this outcome (B\#47;11).

Although none of my businessmen informants thinks that the headscarf can/should be abandoned, they -except the one mentioned above- seem to interpret Fethullah Gulen's statement on the headscarf in a context of social realities and to understand it as a temporary permission rather than a permanent one. The following quotation gives this impression:

Fethullah Gulen's statement on the headscarf is a product of the difficulties that we are living by... it is a statement

16 In the literature on Islamic law, farzi-ayn refers to religious duties that are mandatory for every Muslim who is subject to those duties. Farzi-kifaye, on the other hand, refers to religious duties that are mandatory for some members of a relevant group but not for every single member of that group. 
to overcome those difficulties. By this statement, Fethullah Gulen Hocaefendi did not mean a permanent abandonment of the headscarf. The permission to abandon the headscarf in this statement was not meant for everybody either. To use this permission or not is up to individuals. He gave this permission because he does not want our people to be without education... In addition, there are many families with low income. If young people quit their college education because of the headscarf issue, then, their families will suffer because those young people will be unable to contribute to the income of their families. Hocaefendi's statement is an easiness for those types of people. As such, it is a quite reasonable attitude. If I were poor, I would want my daughters to use this permission $(B \# 51 ; 5)$.

In contrast, intellectuals/cadres of the nurju movement take a strong critical position concerning Fethullah Gulen's statement regarding the headscarf. Respondent \#24, for instance, expresses his feelings toward the Fethullah Gulen group by telling his observations upon the violation of Islamic dress code among the members of this group:

I was in England a while ago to participate in a meeting. A friend pointed a lady from a distance. She was not wearing a headscarf; her arms were not covered either. "Look at this lady," he said. "She is the person who organizes the reading services of the Fethullah Gulen group here." I was shocked when I heard that. I got upset because she was kind of a local leader in the area in the name of an Islamist group and she was not observing the Islamic dress code. Later on, I witnessed several other cases like this in Turkey. I realized that all female students residing in the Fethullah Gulen group's dorms abandoned their headscarves due to Hocaefendi's order. When I asked a friend from this group about why this was happening, he said: "I do not understand this either. Hocaefendi says that he definitely did not give any order to abandon the headscarf but when I ask the managers of those dorms, they say they 
got an order from above." Anyway, Fethullah Gulen's statements and attitudes toward the headscarf are totally against the Islamic Law (serr-i serife aykiri). The very first conviction of Bediuzzaman Said Nursi was due to his writings upon Islamic dress code (tesettur risalesi). On this issue, Fethullah Gulen obviously took a non-nurju position (I\#24;7).

Fethullah Gulen's statements regarding the headscarf were meant to save the organizations and activities of the group against a likely attack from secularist state rulers, respondent \#1 thinks. However, he also thinks that this attitude made things worse for the group:

After his statements regarding the headscarf, state rulers did not say, "Oh, you are OK; you are in our side." Quite contrary, they said: "You are hiding your true attitudes (sen takiyye yapiyorsun); therefore, you are even more dangerous;" they attacked him as we all witnessed. As a result, he cannot come to the country now. This shows that these kinds of tactics are useless. The more you try to disguise yourself, the more suspicious they [secularist rulers] get about you (C\#1;24).

Furthermore, respondent \#4 argues that Fethullah Gulen's statements regarding the headscarf caused a lot of damage within his group itself too. By this he means a likely breakage within the group:

The social basis of the Fethullah Gulen group is similar to that of the Nurju movement. When, for some reason, there is a breakage to come in such movements, it does not come in a noisy fashion; rather it takes place silently. People get sulky. The circulation of Daily Zaman, for instance, has dropped from 300,000 to 150,000 in a year right after Fethullah Gulen's statements regarding the headscarf. This is a serious indication of reaction by the followers of this group. (C\#4;14).

Fethullah Gulen's statement on the headscarf was a "big tactical mistake," according to respondent \#4, because 
The people of Gaziantep started their military resistance against the French occupation forces largely because they attacked Muslim women's headscarves. The headscarf is the honor of a Muslim woman; without it, she feels as if she is naked (C\#4;14).

\subsection{The Strictly Hierarchical Structure of the Fethullah Gulen Group}

It is no secret that the Fethullah Gulen group carries out an enormous number of activities within and outside of the country. It is also not a secret that all those activities are carried out in a highly hierarchical $\operatorname{order}^{17}$. Is this hierarchical order something encouraged or tolerated by the general philosophy of the Risale-I Nur? Intellectuals/cadres of the nurju movement do not think so. On the contrary, they think that this is the opposite of what the Risale-I Nur advises. Respondent \#20, for example, opposes such a hierarchical order in terms of its outcomes:

The Risale-I Nur advocates the emergence and development of a civil society. However, when we look at the Fethullah Gulen group, we see a sort of state structure. Things are run in a strictly structured hierarchical order. This is not peculiar to the Fethullah Gulen group; it is common in other Islamist movements as well. As an outcome of this kind of structuring, there inevitably emerges a sort of official discourse within the group just like the state produces an official discourse. This official discourse does not allow individuals to develop their own views. In the case of the Fethullah Gulen group, we can actually identify two official discourses: one for outsiders, that is, for the state, and the other for the insiders. I guess what I am trying to say is that, contrary to the case of the Nurju movement, there is no place for pluralism in the Fethullah Gulen group (I\#20;18).

Respondent \#20 also argues that the same hierarchical structure

17 Many researchers highlight this hierarchical structure. See, for instance, Aras and Caha (2000). 
gives no chance for internal democracy within the Fethullah Gulen group. Respondent \#19 draws a similar picture and adds:

Followers of Fethullah Gulen give more value to him than his real capacity. They listen to him as if they were listening to the prophet. As an outcome of this, there is an official discourse within the group and individuals are unable to develop their own views (I\#19;29).

\subsection{The Fethullah Gulen Group's Discourse of Tolerance and Dialog}

The concepts of tolerance and dialog are probably two of the most emphasized themes in Fethullah Gulen's writings ${ }^{18}$. The importance of these concepts shows itself not only in his writings but also in his group's activities. The Fethullah Gulen group, indeed, organized many meetings to stimulate tolerance and dialog between secularist and Islamist intellectuals and politicians as well as between the leaders of different religious communities both within and outside of the country ${ }^{19}$.

The reaction of the nurjus toward these activities is positive in general. In fact, respondent \#24 asserts that it was the nurjus who first attempted to organize meetings to stimulate tolerance and dialog among ideological and religious positions and that the Fethullah Gulen group imitated the nurjus despite the fact that the Fethullah Gulen was not initially in favor of such attempts.

However, intellectuals/cadres of the Nurju movement also tend to criticize the Fethullah Gulen group in terms of the direction of attempts toward tolerance and dialog toward the other. The following quotation from respondent $\# 19$ summarizes their major criticism on this matter:

Tolerance and dialog are certainly positive attitudes in Islam. However, in terms of tolerance and dialog, Bedi-

18 See, for instance, Gulen (1996). For a collection of Fethullah Gulen's speeches on tolerance and dialog, see Camci and Unal (1999).

19 The Foundation for Journalists and Writers plays the most significant role in the organization of those meetings. The list and content of those meetings are available in various publications of this foundation. 
uzzaman Said Nursi encourages us to start from the center to the periphery. This is also one of the Qur'an's main principles. Nonetheless, the Fethullah Gulen group seems to adopt exactly the opposite of this principle. Fethullah Gulen puts a great emphasis on tolerance to and dialog with the other. He does not reveal the same attention to Muslims though; rather, he definitely hurts the feelings of Muslims. In a funeral, for instance, he waited in his car just to avoid meeting with Mahmut Effendi. TV channels broadcasted this for minutes. He does not want to meet with a respected Muslim spiritual leader but he is very enthusiastic in meeting with the Pope or with other non-Muslim leaders. This offends Muslims and it is definitely against the Risale-I Nur. The healthy way of tolerance and dialog is supposed to start from the center, and then to be spread to the periphery, not the other way around (I\#19;23).

\subsection{The Discourse of Turkish Islam}

The concept of Turkish Islam has a long history going back to the late 19th century. Fethullah Gulen too has been referring to this concept for a while20. However, Gulen's use of this concept is supposedly different than those who use it to mean a process of Turkifization/reformation of Islam. In referring to this concept, as far as I can see, Gulen seems to imply that, compared to other nations -Arabs and Iranians in particular- Anatolian Turks developed and adopted a better understanding of Islam based on tolerance to the other and on humanistic values, which is closer to the original true Islam. As such, his use of this concept does not imply any modification or reformation of Islam but highlights the superiority of Turks' understanding and practice of Islam over other nations'.

The reaction of the nurjus toward the use of this concept ranges from different levels of approval to a total rejection. Some businessmen nurjus, like respondent $\# 51$, personally do not like the use of this

20 Gulen's views on Turkish Islam as well as on Iran and Arabs can be found in an interview published in Yeni Yuzyil, 19-28 July 1997. 
concept but think that Fethullah Gulen is a great Islamic scholar; therefore, if he is using such a concept, then he must have a good reason. Some other businessmen nurjus, however, seem to see the content of this concept as factual. Respondent \#41, for instance, interprets this concept as implying a better understanding of Islam by Turks and gives the following explanation to justify this interpretation:

Other Islamic societies might be richer than us but their educational and cultural level is lower than ours. Turkey has developed close relations with the West over time; an outcome of those relations has been a more developed educational and cultural structure in Turkey. This, in turn, gave the Turks the advantage of developing better and true Islamic views $(B \# 41 ; 7)$.

Unlike businessmen nurjus, the use of this concept creates dislikes and discomforts among nurju intellectuals/cadres. The following quotation reflects how they evaluate Fethullah Gulen's use of this concept:

I do not think a proper understanding and practice of Islam can be limited to Turks only. Every nation has people with a proper understanding and practice of Islam and also people with no such understanding and practice. The use of this concept is a reflection of hostility against Arabs and Iranians. I think that Fethullah Gulen and people like him have the following concern: the official ideology in Turkey is concerned that we might be influenced by fundamentalist movements, which are common among Arabian and Iranian regimes. In the light of this, we need to persuade the state rulers that this is not the case for us. In other words, by using this concept, Fethullah Gulen wants to give this message: "We are not like Iran, not like Saudi Arabia, etc. We are different." This is an understandable tactic but I still think it is wrong to use concepts like this because concepts like Turkish Islam brings a lot of ambiguities and arbitrary interpretations on Islam and because it is based on a non-Islamic literature. This concept implies that Turkishness is the essence of our iden- 
tity while Islam is a complementary factor. However, we believe that we are first Muslims, then Turks (C\#10;25).

Respondent \#19 argues that concepts like Turkish Islam are fabricated to satisfy the military rulers. Although he agrees that there might be some minor differences in the practice of Islam among different nations and ethnic groups, he thinks that this cannot justify the use of such concepts because Islam is universal. He sees a significant similarity between military mentality and the use of concepts like Turkish Islam:

A friend of mine told me a past memory of his: He knew a retired general. To show how religious he was, this general pointed out the sky and told my friend: "if you could cut the sky, you could see Allah's throne in the middle. On His right, you could see Ataturk's throne. On His left, you could see Inonu's throne, and on Inonu's left, you could see my grandfather's throne." So, this is the mentality of military men. Unfortunately, people among us fabricate such concepts to satisfy the feelings of such military men. As a result, Islam becomes unrecognizable in the hands of those people (I\#19;31).

\section{Discussion}

The research findings can be summarized as follows: Businessmen nurjus generally hold a positive view toward the Fethullah Gulen group. They tend to locate the group within the Nurju movement by looking at "the spirit of the Risale-I Nur's general philosophy" and/or the benefits generated by the group's activities. They do have some points of disagreement but they try to understand those points within the political context the group has to operate in. In other words, they are aware of the seeming differences between the group and the Nurju movement but they see those differences as inevitable outcomes of the types of activities the group has been undertaking. Furthermore, the account of businessmen nurjus about the Fethullah Gulen group suggests that the Fethullah Gulen group is less ideological and more pragmatic in their attitudes regarding controversial issues taking place in Turkey. 
Intellectuals/cadres of the Nurju movement, on the other hand, seem to be more inclined to highlight the differences and to locate the group in the margins of the Nurju movement, if not completely outside of it. In doing so, they stress the differences on the role of the Risale-I Nur vs. the role of Fethullah Gulen, the goal of saving people's faith vs. the goal of getting state control, and attitudes toward political actions concerning Islamist groups vs. attitudes of silence toward such political actions.

What is the meaning of those findings? What do they tell us? My interpretation of those findings has two dimensions: 1) the explanation of the differences on views between businessmen and intellectuals/ cadres of the movement, and 2) socio-political implications. I will discuss both dimensions in turn.

By logic, one can assume that the perception of the Fethullah Gulen group might differ by group affiliation. In other words, those who follow the Fethullah Gulen group would reveal sympathetic views and those who follow a different group might have critical views. By not covering members of the Fethullah Gulen group in the study, I partly eliminated possible effects of group affiliation. All respondents are participants of various mainstream nurju groups. In spite of this elimination, there is still a chance that group affiliation may play a role in the perceptions of the respondents.

However, I think that group affiliation (being a nurju) is more likely to be effective on the views of mere followers rather than on that of business elites and intellectuals/cadres of the movement. This is so largely because mere followers usually open their eyes in a particular group/movement and they usually do not develop an accurate knowledge of other groups/movements. Business elites and intellectuals/ cadres, on the other hand, are more likely to have certain types of relations with a broader number of groups/movements and, as a result, they are more likely to have more accurate knowledge of various groups/ movements. This is confirmed by my finding that business elites of the Nurju movement tend to develop social and economical relations not only with various groups of the Nurju movement but also with mystic and radical groups of overall Islamist movements. Intellectuals/cadres 
have the same tendency due to the fact that they need to address to as large audience as possible.

Both businessmen and intellectuals/cadres need to keep their relations as broad as possible because, in a sense, both types of nurjus have something to market: businessmen market their products while intellectuals/cadres market their intellectual works and services. This does not necessarily mean that they are involved in the Nurju movement just to market what they have. I have no doubt that they are involved in the movement because they believe in major principles of the movement. However, being a believer and an interest-maximizer does not have to be contradictory at all.

Ethnic origins too might be suggested as another explanatory factor. If those who hold critical views on the Fethullah Gulen group were coming from Kurdish origin, for instance, then we could conclude that they criticize the Fethullah Gulen group because this group holds strong Turkish nationalist attitudes. However, this is not the case. In fact, all but one of my intellectual/cadre respondents comes from Turkish ethnic origin while three of my businessmen respondents come from Kurdish ethnic origin. Therefore, ethnic origin, in this case, cannot be taken as an explanatory factor either.

Then, how can we account for these differences? Despite the current tendency to evaluate class analysis as an old-fashioned determinist approach, I find it as a better explanatory factor especially for the question under discussion than any other factors. Without denying the role of religious/ideological beliefs, I think that the differences on views under study can be better explained in terms of class positions (in particular class fractions) that businessmen and intellectuals/cadres belong to.

The overall impression gathered from the accounts of both businessmen nurjus and intellectual/cadre nurjus is that the Fethullah Gulen group seems to try mediating between moderate Islamists and secularists; it is also making strategic compromises with the state to increase power and/or to get some legitimacy or at least not to antagonize the authorities. How those compromises are evaluated varies by class interests. Those who will benefit most excuse these as necessary, pragmatic 
choices while those who see less benefit accuse the Fethullah Gulen group of being "flaky" or "not true followers of the Risale-I Nur."

Businessmen nurjus tend to develop a positive view of the Fethullah Gulen group largely because the activities of this group are in favor of their interests. As an emerging indigenous industrial class, nurju businessmen are seeking some support from the state bureaucracy who could treat them equally, if not favorably. The Fethullah Gulen group's efforts toward the state bureaucracy are likely to provide such a support for businessmen nurjus. Furthermore, the Fethullah Gulen group's discourse of tolerance and dialog with secularists and that group's careful efforts to avoid from any controversies with the state rulers -as in the case of the headscarf issue- are quite suitable with the interests of businessmen nurjus because such activities would provide stability in the country; therefore, they would give the opportunity for businessmen nurjus to further increase their economic power without state oppression.

On the other hand, the position of nurju intellectuals/cadres in class conflict in Turkey is a bit different than that of businessmen. They are in a kind of alliance with the emerging indigenous industrial class (businessmen nurjus) but they have their own priorities too. Ideological identity/loyalty is their main capital in the market of social movements. Their status in this market gets higher as long as they stay loyal to their ideology. This is why they tend to evaluate the Fethullah Gulen group more along ideological lines and why they feel freer to criticize them. However, one also should keep in mind that most of the nurju intellectuals/cadres still hesitate to express publicly their critical vi$\mathrm{ews}^{21}$ on the Fethullah Gulen group because, for them, there is always the possibility of employment within this group (in schools or media, for instance).

Finally, I read the research findings as having several political implications for the future of the Fethullah Gulen group. One of those

21 There are exceptions though. Mehmet Kutlular, the leader of the Yeni Asya Nurju group, for instance, openly criticized Fethullah Gulen in similar lines as my critical respondents did. See Milliyet, 26 June 1999. 
implications is that the Fethullah Gulen group fails to present a clear image about itself. Although the group seems to be doing its best to appear as willing to compromise with the state (i.e., the headscarf issue, the discourse of tolerance and dialog, the discourse of Turkish Islam), it also appears as more confrontational (the videocassette affair, the strictly hierarchical structure, etc.). The unclear and contradictory presentation of itself leads not only secularists but also some segments of the Nurju movement to develop suspicious views on the goals and characteristics of the Fethullah Gulen group.

Secondly, out of those suspicious views, there emerges a picture of the Fethullah Gulen group that interestingly resembles the picture describing radical Islamism. Impressions of a strictly hierarchical structure and that of the goal of state control reinforce this resemblance. The strictly hierarchical structure of the Fethullah Gulen group is indirectly indicating the prevalence of the view that a strong and unitary leadership is required for success. In contrast to both Eastern Christianity and Catholicism, Islam does not recognize the supreme authority of one religious leader. In this sense, Fethullah Gulen's role seems less traditional. It may be the result of the realization of the effective leadership role of Khomeini or, simply, of the realization that unitary leadership is necessary to coordinate the complicated development of the whole Nurju movement. However, the Fethullah Gulen group may soon lose the support of secularist intellectuals and politicians -if it still has such a support at all- if those impressions keep growing.

Finally, unless there is a fundamental change in its political stand, the Fethullah Gulen group is likely to continue having the support of businessmen nurjus but less likely to have that of nurju intellectuals/cadres. The support of businessmen nurjus is very important because the activities of the Fethullah Gulen group are heavily dependent on the financial support of the businessmen nurjus. However, the support of nurju intellectuals/cadres is as important as that of businessmen nurjus because it is the intellectuals/cadres who play the intermediary role between the top and mass followers. Without the support of nurju intellectuals/cadres, the Fethullah Gulen group may lose much of its social support in Turkish society. 


\section{References}

Aras, Bulent and Omer Caha (2000): "Fethullah Gulen and His Liberal 'Turkish Islam' Movement" in www.wisdom.net

Camci, Selcuk and Kudret Unal (1999): Fethullah Gulenin Konusma ve Yazilarinda Hosgoru ve Diyalog Iklimi (Tolerance and Dialog in the Writings and Speeches of Fethullah Gulen): Izmir:Merkur Yay.

Gulen, Fethullah (1996): Fasildan Fasila (From Chapter to Chapter); Izmir: Nil Yay.

Evans, Peter (1979): Dependent Development: The Triple Alliance of Multinational, State and Local Capital in Brazil (New Jersey: Princeton University Press).

Kaynak Yayinlari (1999): Bati ve Irtica (the West and Fundamentalism), (Istanbul: Kaynak Yay.). No editor.

Komecoglu, Ugur (2000): "Kutsal ile Kamusal: Fethullah Gulen Cemaat Hareketi" (the Sacred and the Public: the Fethullah Gulen Community Movement) in Nilufer Gole (ed.): Islamin Yeni Kamusal Yuzleri (New Public Faces of Islam); Istanbul: Metis Yay.

Mardin, Serif (1989): Religion and Social Change in Modern Turkey: The Case of Said Nursi (Albany: SUNY Press).

Nereid, Camilla Trud (1997): In the Light of Said Nursi: Turkish Nationalism and the Religious Alternative (London: C. Hurst \& Co. Ltd.).

Shaffir, William B. and Robert A. Stebbins (1991): Experiencing Fieldwork: An Inside View Of Qualitative Research (Newbury Park: Sage Publications).

Yavuz, M. Hakan (1998): The Construction of Islamic Identity in Turkey: 1960-1997 (Unpublished Dissertation, University of Wisconsin-Madison). (1999): "Toward an Islamic Liberalism?: The Nucu Movement and Fethullah Gulen" in Middle East Journal, Vol.53, No. 4. 